\title{
PENGARUH KELENGKAPAN PENGISIAN FORMULIR TRANSFER PASIEN INTERNAL TERHADAP MUTU REKAM MEDIS
}

\author{
Indar Farwanti Wahyuni ${ }^{1 *}$,Sali Setiatin ${ }^{2}$, Aris Susanto ${ }^{3}$ \\ 1 Politeknik Piksi Ganesha
}

2 Politeknik Piksi Ganesha

Corresponding author: Indar Farwanti Wahyuni

Politeknik Piksi Ganesha

Email: indarfarwantiwahyuni@gmail.com

\section{Article Info:}

Dikirim: 06 Juli 2021

Ditinjau: 23 Agustus 2021

Diterima: 08 November 2021

DOI:

https://doi.org/10.33475/jikmh.v7i2.21

\begin{abstract}
Internal patient transfer is the process of transferring patients from one room to another in a hospital while still being oriented towards quality and patient safety. The results of the observations showed that the filling of the internal patient transfer form was not optimal so that there were still incomplete forms due to the large number of patients and the weak coordination between health workers. To determine the effect of the completeness of filling out the internal patient transfer form on the quality of medical records. The research method used is quantitative with a descriptive approach. Data collection techniques used are observation, questionnaires and literature study. The sampling technique was simple random sampling technique so as to obtain a sample of 91 internal patient transfer forms. From the results of observations, $22 \%$ of the internal patient transfer forms were found that were not completely filled in, especially in the signature and clear name. The two variables have a strong relationship. The effect of the variable completeness of the internal patient transfer form on the medical record quality variable is $90.1 \%$ and the remaining $9.9 \%$ is influenced by other factors. Based on these studies, it can be concluded that the lack of accuracy and coordination of nurses, doctors and other officers in filling out internal patient transfer forms so that this affects the quality of medical records in the aspect of accuracy.

Keyword : Completeness, Internal Patient Transfer Form, Medical Record Quality
\end{abstract}

Kata kunci: Kelengkapan, Formulir Transfer Pasien Internal, Mutu Rekam Medis 


\section{PENDAHULUAN}

Pelayanan kesehatan yang berkembang di Indonesia sangat beragam macamnya, salah satunya adalah rumah sakit. Rumah sakit memberikan pelayanan menyeluruh dan paling kompleks dibanding dengan fasilitas pelayanan kesehatan lainnya. Berdasarkan Peraturan Menteri Kesehatan Republik Indonesia No. 30 Tahun 2019 Bab I, dalam pasal 1 ayat 1 disebutkan bahwa rumah sakit adalah institusi pelayanan kesehatan yang menyelenggarakan pelayanan kesehatan perorangan secara paripurna yang menyediakan pelayanan rawat inap, rawat jalan dan gawat darurat. Rawat inap merupakan salah satu pelayanan yang diberikan tirah baring di rumah sakit. Segala aktivitas kegiatan yang dilakukan didalam pelayanan rawat inap dicatat dengan lengkap dan jelas didalam rekam medis sesuai kebijakan yang ada.

Peraturan Menteri Kesehatan Republik Indonesia No. 269/MENKES/PER/III/2008 bab III, pasal 7 disebutkan bahwa sarana pelayanan kesehatan wajib menyediakan fasilitas yang diperlukan dalam rangka penyelenggaraan rekam medis. Salah satu sarana pelayanan yang berkaitan dengan penyelenggaraan rekam medis adalah transfer pasien. Transfer pasien adalah kegiatan yang dilakukan dalam hal perpindahan pasien dari satu ruang perawatan ke ruang perawatan lainnya, baik didalam rumah sakit maupun antar rumah sakit. Kegiatan tersebut bertujuan untuk memastikan keselamatan serta keamanan pasien saat akan melakukan perpindahan tempat perawatan.

Proses dari transfer pasien dapat dimulai dengan cara koordinasi serta komunikasi pra transportasi pasien, mempersiapkan peralatan yang disertakan saat melakukan transfer pasien, monitoring pasien selama melakukan transfer, dan tentunya telah menentukan Sumber Daya Manusia (SDM) yang akan mendampingi pasien. Kegiatan ini hanya boleh dilakukan oleh staf medis dan staf keperawatan yang kompeten serta petugas lainnya yang sudah profesional dan terlatih. (Association of Anaesthetists of Great and Ireland, 2009).

Guna mendapatkan penilaian serta penetapan kelayakan rumah sakit berdasarkan standar pelayanan yang telah ditetapkan oleh lembaga penyelenggara akreditasi, maka rumah sakit wajib melakukan akreditasi rumah sakit sesuai pada undang-undang No. 44 tahun 2009, pasal 40 ayat 1 disebutkan bahwa dalam upaya peningkatan mutu pelayanan rumah sakit secara berkala minimial tiga (3) tahun sekali. Menurut Peraturan Menteri Kesehatan No. 12 tahun 2012 bahwa akreditasi rumah sakit, selanjutnya disebut akreditasi, adalah pengakuan terhadap rumah sakit yang diberikan oleh lembaga independen penyelenggara akreditasi yang ditetapkan oleh menteri, setelah dinilai bahwa rumah sakit itu memenuhi standar pelayanan rumah sakit yang berlaku untuk meningkatkan mutu pelayanan rumah sakit secara berkesinambungan.

Mutu merupakan keseluruhan dari bentuk karakteristik dilihat dari baik buruknya suatu barang atau jasa yang dihasilkan dan terdapat rasa aman serta terpenuhnya kebutuhan para pengguna barang atau jasa yang dihasilkan. Menurut Azwar (2010: 55) secara sederhana hakekat mutu antara lain : (a) mutu adalah tingkat kesempurnaan dari penampilan sesuatu yang sedang diamati, (b) mutu adalah sifat yang dimiliki oleh suatu program, (c) mutu adalah kepatuhan terhadap standar yang telah ditetapkan, (d) mutu adalah totalitas dari wujud serta ciri dari suatu barang atau jasa yang didalamnya terkandung sekaligus pengertian rasa aman atau pemenuhan kebutuhan pengguna. Menurut Dirjen Yanmed (2006: 75) rekam medis dapat dikatakan berkualitas ketika telah dilakukan analisa pada mutunya dengan maksud: (a) agar rekam medis lengkap dan dapat digunakan bagi referensi pelayanan kesehatan, 
melindungi minat hukum, sesuai dengan peraturan yang ada, (b) menunjang informasi untuk aktifitas penjamin mutu (quality assurance), (c) membantu penetapan diagnosis dan prosedur pengkodean kepenyakitan, dan (d) bagi riset medis, studi administrasi dan penggantian biaya perawatan. Analisa mutu rekam medis sangat penting untuk dapat memberikan nilai kelayakan pada rumah sakit, sehingga para tenaga unit rekam medis wajib melengkapi berkas rekam medis, salah satu dari kegiatannya yaitu dengan memperhatikan kelengkapan pengisian formulir transfer paien internal yang dilakukan oleh tenaga kesehatan tertentu selama masa perpindahan ruang perawatan pasien.

Berdasarkan observasi yang dilakukan di Rumah Sakit X Kota Bandung, ditemukan fenomena yang terjadi yaitu formulir transfer pasien internal yang tidak terisi lengkap sebanyak 20 atau 22\% dari 91 atau $100 \%$ formulir. Fenoma tersebut menunjukkan bahwa belum optimalnya pengisian formulir transfer pasien internal diduga disebabkan oleh faktor banyaknya pasien dan lemahnya koordinasi staf medis, staf keperawatan serta tenaga profesional lainnya.

Adapun saran yang diberikan diantaranya, melakukan monitoring dan evaluasi oleh panitia rekam medis dan komite medik secara berkala kepada dokter maupun perawat mengenai pentingnya melengkapi formulir transfer pasien internal untuk meningkatkan mutu rekam medis dan memberikan pelatihan yang bertujuan untuk menambah wawasan atau pengetahuan pada bidang rekam medis dalam upaya peningkatan mutu rekam medis serta perlunya pengawasan kepada dokter maupun perawat akan kelengkapan dan ketepatan penulisan formulir transfer pasien internal sesuai dengan standar operasional prosedur (SOP) yang telah ditetapkan.

\section{METODE}

Jenis penelitian ini adalah kuantitatif dengan pendekatan deskriptif. Menurut Sugiyono (2018:16) metode penelitian kuantitatif dapat diartikan sebagai metode penelitian yang berlandaskan pada filsafat positivisme, digunakan untuk meneliti pada populasi atau sampel tertentu, pengumpulan data menggunakan instrumen penelitian, analisis data bersifat kuantitatif/statistik, dengan tujuan untuk menguji hipotesis yang telah ditetapkan. Penelitian deskriptif juga dapat di definiskan sebagai suatu penelitian yang dilakukan untuk mendeskripsikan atau menggambarkan suatu fenomena yang terjadi di dalam masyarakat (Notoatmojo, Soekidjo, 2018: 35-36).

Objek penelitian ini merupakan data berupa angka/presentase kelengkapan pengisian formulir transfer pasien internal dengan cara mengumpulkan data kelengkapan dan mengamati secara seksama masalah yang ada dengan memperhatikan aspek-aspek tertentu sehingga akan diperoleh data-data yang akan menunjang penyusunan laporan penelitian. Metode pengambilan sampel yang digunakan adalah simple random sampling. Menurut Notoatmojo, Soekidjo (2018: 120) mengatakan bahwa, simple random sampling adalah bahwa setiap anggota atau unit dari populasi mempunyai kesempatan yang sama untuk diseleksi sebagai sampel. Jumlah sampel yang digunakan dalam penelitian ini sebanyak 91 formulir transfer pasien internal.

Dalam menyusun penelitian ini digunakan beberapa teknik pengumpulan data yaitu: teknik pengamatan (observasi), kuesioner dan studi pustaka. Metode analisa yang digunakan adalah metode analisa statistik dengan menggunakan software IBM SPSS 20. Teknik pengumpulan data pada penelitian ini yaitu dengan metode pengolahan data kuesioner dari 20 orang 
responden yang terdiri dari Variabel bebas (independen variabel) dan Variabel Terikat (dependent variabel). Dalam penelitian ini digunakan uji validitas kuesioner dengan menggunakan uji pearson correlation. Jika nilai $\mathrm{R}_{\text {hitung }}$ lebih besar dari $\mathrm{R}_{\text {tabel }}\left(\mathrm{N}=20, \mathrm{R}_{\text {tabel }}=0,443\right)$ maka kuesioner dianggap valid. Untuk uji reliabilitas kuesioner digunakan uji cronbach alpha coefficient. Jika nilai cronbach alpha coefficient diatas 0,6 maka kuesioner dianggap reliabel serta dilakukan uji regresi linear sederhana digunakan perbandingan nilai signifikansi dengan nilai probabilitas $<0,05$ dan uji koefisien determinasi untuk mengetahui pengaruh variabel bebas (kelengkapan formulir transfer pasien internal) terhadap variabel terikat (Mutu Rekam Medis).

Tabel 1. Kerangka Konsep

Menurut Rano Indradi (2017)

Menurut Dirjen Yanmed (2006:73)

\begin{tabular}{|l|l|l|}
\hline $\begin{array}{c}\text { Kelengkapan Formulir } \\
\text { Transfer Pasien Internal } \\
(\mathrm{X})\end{array}$ & \multicolumn{1}{|c|}{$\begin{array}{c}\text { Mutu Rekam Medis } \\
(\mathrm{Y})\end{array}$} \\
\hline 1. Identifikasi Pasien & & $\begin{array}{l}\text { 1. Lengkap } \\
\text { 2. Akurat } \\
\text { 2. Laporan Penting }\end{array}$ \\
$\begin{array}{ll}\text { 3. Autentifikasi } \\
\text { 4. Pencatatan }\end{array}$ & $\begin{array}{l}\text { 3. Tepat Waktu } \\
\text { 4. Memenuhi Aspek } \\
\text { Hukum }\end{array}$ \\
\hline
\end{tabular}

Tabel 2. Hasil Uji Validitas

\begin{tabular}{|c|c|c|c|}
\hline No & Item Pertanyaan & Pearson correlation & Keterangan \\
\hline 1 & Pertanyaan 1 & 0,963 & Valid \\
\hline 2 & Pertanyaan 2 & 0,942 & Valid \\
\hline 3 & Pertanyaan 3 & 0,948 & Valid \\
\hline 4 & Pertanyaan 4 & 0,942 & Valid \\
\hline 5 & Pertanyaan 5 & 0,963 & Valid \\
\hline 6 & Pertanyaan 6 & 0,941 & Valid \\
\hline 7 & Pertanyaan 7 & 0,904 & Valid \\
\hline 8 & Pertanyaan 8 & 0,963 & Valid \\
\hline 9 & Pertanyaan 9 & 0,941 & Valid \\
\hline 10 & Pertanyaan 10 & 0,803 & Valid \\
\hline 11 & Pertanyaan 11 & 0,906 & Valid \\
\hline 12 & Pertanyaan 12 & 0,906 & Valid \\
\hline 13 & Pertanyaan 13 & 0,904 & Valid \\
\hline 14 & Pertanyaan 14 & 0,912 & Valid \\
\hline 15 & Pertanyaan 15 & 0,820 & Valid \\
\hline
\end{tabular}

Berdasarkan tabel diatas dapat disimpulkan bahwa semua pertanyaan pada kuesioner pengaruh

kelengkapan pengisian formulir transfer pasien internal terhadap mutu rekam medis dikatakan valid karena nilai korelasi tiap pertanyaan dengan total menunjukkan nilai korelasi lebih dari 0,443 .

Tabel 3. Uji Relibilitas

Reliability Statistics

\begin{tabular}{ll}
\hline Cronbach's Alpha & N of Items \\
\hline 0,986 & 15
\end{tabular}

Hasil dari tabel uji relibilitas diatas menunjukkan bahwa nilai cronbach's alpha adalah 0,986 dari jumlah $\mathrm{N}$ sebanyak 15 item. Dikatakan reliabel jika cronbach's alpha lebih dari 0,6. Maka hasil uji statistika cronbach's alpha diatas mengindikasikan kuesioner pengaruh kelengkapan formulir transfer pasien internal terhadap mutu rekam medis dikatakan reliabel.

\section{HASIL DAN PEMBAHASAN}

\section{Hasil Presentase Kelengkapan Pengisian Formulir Transfer Pasien Internal}

Dari hasil penelitian yang dilakukan mengenai pengaruh kelengkapan pengisian formulir transfer pasien internal terhadap mutu rekam medis, terdapat 71 atau $78 \%$ formulir transfer pasien internal yang lengkap dan 20 atau $22 \%$ formulir transfer pasien internal yang tidak lengkap dari total 91 sampel yang diambil selama triwulan I 2021. 


\section{Kelengkapan Pengisian Formulir Transfer Pasien Internal Triwulan I 2021}

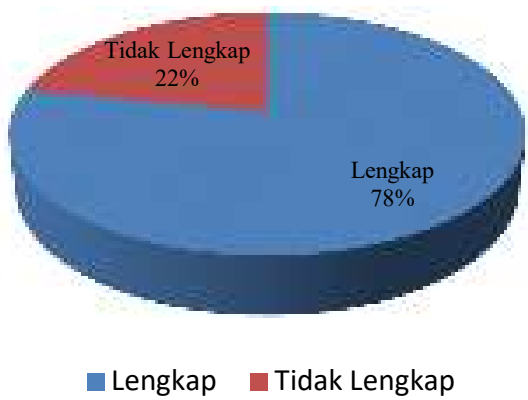

Gambar 1. Kelengkapan Pengisian Formulir Transfer Pasien Internal Triwulan I 2021

Pada gambar 1. terlihat jelas bahwa ada $22 \%$ formulir transfer pasien internal yang diisi tidak lengkap dengan ketidaklengkapan tertinggi terdapat pada pencatatan $21,98 \%$ di tabel 4. Hal tersebut bisa dilihat bahwa kurangnya kedisiplinan dalam hal pencatatan transfer pasien internal dari tenaga kesehatan terkait membutuhkan tandatangan dan nama jelas.

Tabel 4. Kelengkapan Transfer Pasien Internal

\begin{tabular}{|l|c|c|c|c|c|c|}
\hline $\begin{array}{c}\text { Kelengkapan } \\
\text { Transfer } \\
\text { Pasien Internal }\end{array}$ & $\mathrm{L}$ & $\% \mathrm{~L}$ & $\mathrm{TL}$ & $\% \mathrm{TL}$ & $\begin{array}{c}\text { TOT } \\
\mathrm{AL}\end{array}$ & \%TOTAL \\
\hline $\begin{array}{l}\text { Review } \\
\text { Identifikasi }\end{array}$ & 91 & $100 \%$ & 0 & $0 \%$ & 91 & $100 \%$ \\
\hline $\begin{array}{l}\text { Review } \\
\text { Laporan } \\
\text { Penting (Isi } \\
\text { Informasi) }\end{array}$ & 73 & $\begin{array}{c}80,43 \\
\%\end{array}$ & 18 & $\begin{array}{c}19,5 \\
7 \%\end{array}$ & 91 & $100 \%$ \\
\hline $\begin{array}{l}\text { Review } \\
\text { Autentifikasi }\end{array}$ & 83 & $\begin{array}{c}91,30 \\
\%\end{array}$ & 8 & $\begin{array}{c}8,70 \\
\%\end{array}$ & 91 & $100 \%$ \\
\hline $\begin{array}{l}\text { Review } \\
\text { Pencatatan }\end{array}$ & 71 & $\begin{array}{c}78,02 \\
\%\end{array}$ & 20 & $\begin{array}{c}21,9 \\
8 \%\end{array}$ & 91 & $100 \%$ \\
\hline
\end{tabular}

Dari hasil review terlihat bahwa data ketidaklengkapan yang paling banyak adalah dari review pencatatan sebanyak 20 formulir atau 21,98\%, kemudian disusul oleh review autentifikasi 8 formulir atau $8,70 \%$ dan review laporan penting (isi informasi) 18 atau 19,75\%. Untuk review identifikasi $100 \%$ sudah terisi dengan lengkap

\section{Hasil Analisis Deskriptif Responden Tentang Kelengkapan Lembar Fomulir Transfer Pasien Internal Terhadap Mutu Rekam Medis}

Diperoleh skor dan persentase hasil kuesioner yang telah diisi oleh 20 petugas Perekam Medis dan Informasi Kesehatan (PMIK).

Tabel 5. Hasil Jawaban Kuesioner Petugas Rekam Medis

\begin{tabular}{|c|c|c|c|c|c|c|}
\hline \multirow{2}{*}{ No } & \multirow{2}{*}{$\begin{array}{c}\text { Item } \\
\text { Pertanyaan }\end{array}$} & \multicolumn{5}{|c|}{ Keterangan } \\
\hline & & SS & $\mathrm{S}$ & $\mathrm{RR}$ & TS & STS \\
\hline 1 & $\begin{array}{l}\text { Semua lembar } \\
\text { transfer pasien } \\
\text { internal } \\
\text { memuat } \\
\text { identifikasi } \\
\text { pasien }\end{array}$ & $55 \%$ & $45 \%$ & - & - & - \\
\hline 2 & $\begin{array}{l}\text { Pada lembar } \\
\text { transfer pasien } \\
\text { internal ada } \\
\text { identitas } \\
\text { keluarga } \\
\text { pasien atau } \\
\text { penanggung } \\
\text { jawab }\end{array}$ & $25 \%$ & $55 \%$ & - & $5 \%$ & $15 \%$ \\
\hline 3 & $\begin{array}{l}\text { Setiap lembar } \\
\text { transfer pasien } \\
\text { internal harus } \\
\text { memuat nama } \\
\text { dan tanda } \\
\text { tangan perawat } \\
\text { yang } \\
\text { mengirim }\end{array}$ & $60 \%$ & $35 \%$ & - & $5 \%$ & - \\
\hline 4 & $\begin{array}{l}\text { Setiap lembar } \\
\text { transfer pasien } \\
\text { internal harus } \\
\text { memuat nama } \\
\text { dan tanda } \\
\text { tangan perawat } \\
\text { yang } \\
\text { menerima }\end{array}$ & $85 \%$ & $10 \%$ & $5 \%$ & - & - \\
\hline 5 & $\begin{array}{l}\text { Pada lembar } \\
\text { transfer pasien } \\
\text { internal harus } \\
\text { memuat nama } \\
\text { dokter } \\
\text { penanggung } \\
\text { jawab } \\
\text { pelayanan } \\
\text { (DPJP) } \\
\end{array}$ & $45 \%$ & $10 \%$ & $5 \%$ & $40 \%$ & - \\
\hline 6 & $\begin{array}{l}\text { Pada lembar } \\
\text { transfer pasien } \\
\text { internal } \\
\text { memuat } \\
\text { diagnosis } \\
\text { medis, } \\
\text { diagnosis } \\
\text { keperawatan, }\end{array}$ & $70 \%$ & $30 \%$ & - & - & - \\
\hline
\end{tabular}




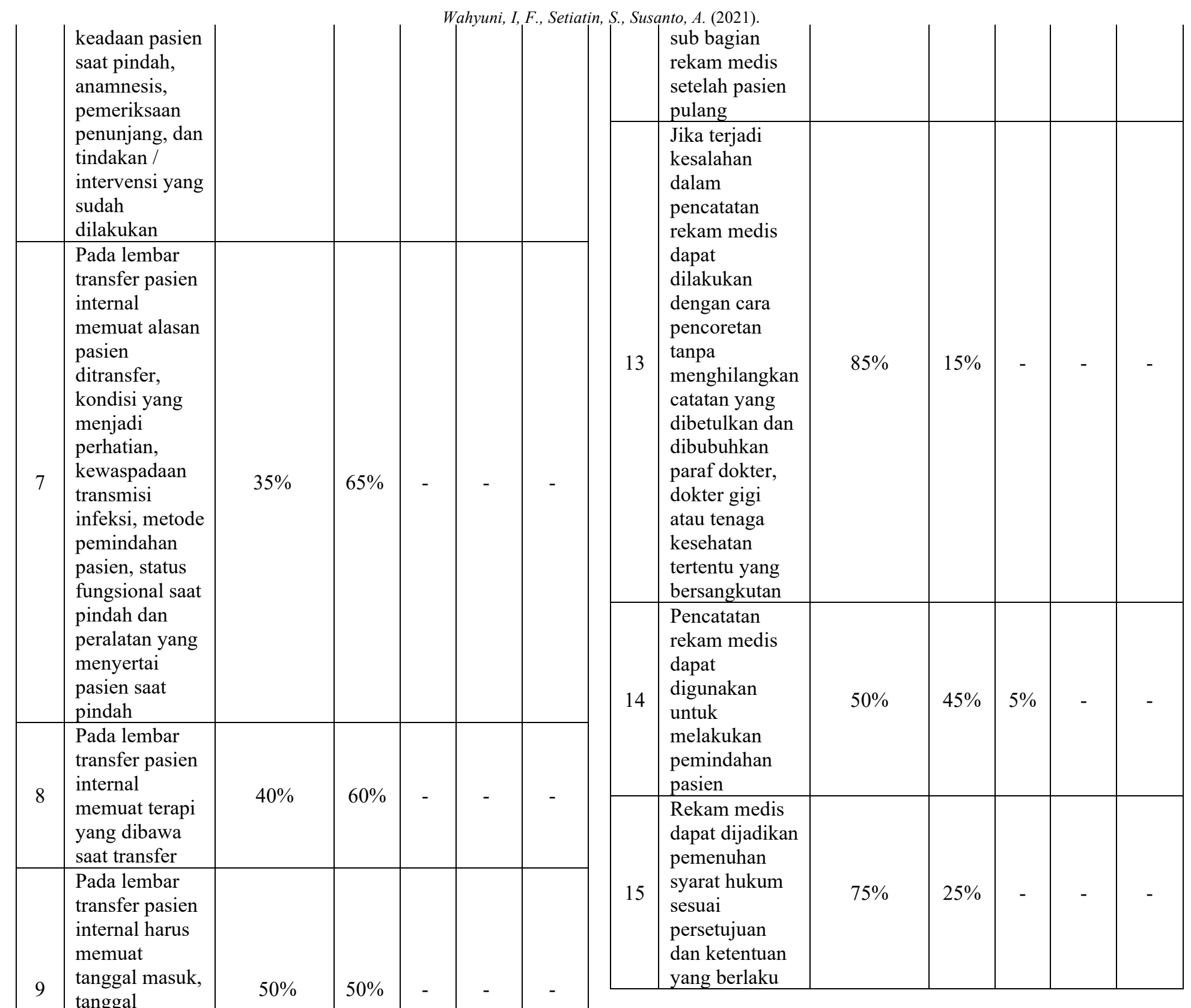

\section{Keterangan :}

SS: Sangat Setuju

TS: Tidak Setuju

S: Setuju

STS: Sangat Tidak Setuju

RR: Ragu-Ragu

\section{Hasil Uji Linear Sederhana}

Pengambilan keputusan dalam uji regresi linear sederhana dapat mengacu pada 2 hal yakni :

Membandingkan nilai signifikansi dengan nilai probabilitas 0,05 
- Jika nilai signifikansi $<0,05$ artinya variabel $\mathrm{X}$ berpengaruh terhadap variabel $\mathrm{Y}$.

- Jika nilai signifikansi $>0,05$ artinya variabel $\mathrm{X}$ tidak berpengaruh terhadap variabel $\mathrm{Y}$.

Tabel 6. ANOVA ${ }^{\mathrm{a}}$

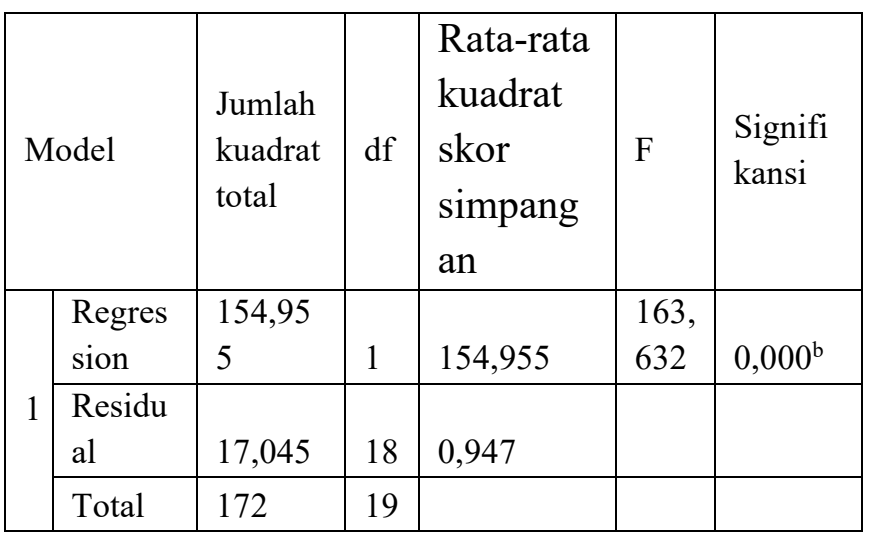

a. Dependent Variable : Mutu_Rekam_Medis

b. Predictors : (Constant)

, Kelengkapan Formulir Transfer Pasien_Internal

Dari output diatas bahwa nilai $\mathrm{F}$ hitung $=163,632$ dengan tingkat signifikansi sebesar $0,000<0,05$, maka model regresi dapat dipakai untuk memprediksi variabel prtisipasi atau dengan kata lain ada pengaruh variabel

Kelengkapan_Formulir_Transfer_Pasien_Internal (X) terhadap variabel Mutu_Rekam_Medis (Y).

\section{Hasil Uji Koefisien Determinasi $\left(R^{2)}\right.$}

\begin{tabular}{|l|l|l|l|l|}
\hline \multicolumn{6}{|c|}{ Tabel 7. Model Summary } \\
\hline Model & $\mathrm{R}$ & $\begin{array}{l}\mathrm{R} \\
\text { Square }\end{array}$ & $\begin{array}{l}\text { Adjusted } \\
\text { Square }\end{array}$ & $\begin{array}{l}\text { Std. Error of } \\
\text { the Estimate }\end{array}$ \\
\hline 1 &, $949^{\mathrm{a}}$ &, 901 &, 895 &, 97312 \\
\hline
\end{tabular}

a. Predictors: (Constant), Kelengkapan Formulir Transfer Pasien Internal

Dari tabel model summary uji regresi linear sederhana diatas dapat disimpulkan yaitu besarnya nilai korelasi / hubungan (R) adalah 0,949. Untuk koefisien determinasi (R Square) diperoleh sebesar 0,901 yang berarti bahwa pengaruh variabel bebas (kelengkapan_formulir_transfer_pasien_internal) terhadap variabel terikat (Mutu_Rekam_Medis) sebesar $90,1 \%$.

\section{KESIMPULAN}

Dari hasil observasi diperoleh kesimpulan yaitu terdapat pengaruh kelengkapan pengisian formulir transfer pasien internal terhadap mutu rekam medis disebabkan oleh kurangnya ketelitian, ketepatan dan koordinasi perawat, dokter dan petugas lain dalam pengisian formulir transfer pasien internal sehingga mempengaruhi mutu rekam medis pada aspek keakuratan. Ditemukannya formulir transfer pasien internal yang belum terisi lengkap sebanyak $22 \%$ terutama pada tandatangan dan nama jelas, hal ini berkaitan dengan autentifikasi. Kedua variabel memiliki hubungan yang kuat. Pengaruh variabel kelengkapan formulir transfer pasien internal terhadap variabel mutu rekam medis sebesar $90,1 \%$ dan sisanya $9,9 \%$ dipengaruhi oleh faktor lain.

\section{DAFTAR RUJUKAN}

Azwar, \& Azrul. (2010). Pengantar Administrasi Kesehatan. Jakarta: Binarupa Aksara.

Depkes. (2009). Undang - Undang No. 44 Tahun 2009 Tentang Rumah Sakit. Jakarta.

Association of Anaesthetists of Great Britain and Ireland (2009). AAGBI safety guideline: interhospital transfer. London.

Kemenkes. (2008). Peraturan Menteri Kesehatan No. 269/Menkes/Per/III /2008 Tentang Rekam medis. Jakarta: Kementerian Kesehatan Republik Indonesia.

Kemenkes. (2012). Peraturan Menteri Kesehatan Republik Indonesia No. 12 Tahun 2012 Tentang Akreditasi Rumah Sakit. Jakarta: Kementerian Kesehatan Republik Indonesia.

Kemenkes. (2017). Peraturan Menteri Kesehatan Republik Indonesia No. 11 Tahun 2017 Tentang Keselamatan Pasien. Jakarta: Kementerian Kesehatan Republik Indonesia.

Kemenkes. (2019). Peraturan Menteri Kesehatan No. 30 Tahun 2019 Tentang Klasifikasi dan 
Perizinan Rumah Sakit. Jakarta: Kementerian Kesehatan Republik Indonesia.

Notoadmojo, \& Soekidjo. (2018). Metodologi Penelitian Kesehatan. Jakarta: Rineka Cipta.

Rano, \& S. Indradi. (2017). Rekam Medis. Tangerang Selatan: Universitas Terbuka.

Sugiyono. (2016). Metode Penelitian Kuantitatif, Kualitatif, dan $R \& D$. Bandung: Alfabeta.

Theresia, S. (2014). Peran Perencanaan Strategis Pada Manajemen Rumah Sakit. Skripsi Universitas Trisakti, Jakarta.

Yanmed, D. (2006). Pedoman Pengelolaan Rekam Medis Rumah Sakit di Indonesia. Jakarta: Binarupa Aksara

Cite this article as: Wahyuni, I, F., Setiatin, S., Susanto, A. (2021). Pengaruh Kelengkapan Pengisian Formulir Transfer Pasien Internal Terhadap Mutu Rekam Medis. Jurnal Ilmiah Media Husada. 10(2)124-131.

https://doi.org/10.33475/jikmh.v7i2.21 